\title{
Daoism as the Philosophic Foundation of Chinese Economic Reform: a Conjecture
}

\author{
Edward J. Romar ${ }^{a^{*}}$ \\ ${ }^{a}$ University of Massachusetts Boston, College of Management, 100 Morrissey Blvd. Boston, MA 02476-3393 USA
}

\begin{abstract}
The reforms of Deng Xiaoping and the opening of China in the 1970s were predicated on something called "socialism with Chinese Characteristics". Deng never explained its meaning in detail. This paper offers a conjecture suggesting that Daoism is the philosophical foundation of Chinese economic reform. Daoism is eminently Chinese and through the concepts of wu wei, yin/yang, qi and others from The Tao Te Ching, the Zhuangzi, and Pheasant Cap Master it offers the flexibility to organize markets within the Chinese context. The paper suggests how a Daoist philosophic foundation supports China's rise both economically and politically. It concludes with the observation that China's long term objective may be something like Zhuangzi's and Pheasant Cap Master's unity and that the West's "end of history" may have past while the Chinese may have just begun.
\end{abstract}

(B)y Marxism we mean Marxism that is integrated with Chinese conditions, and by socialism we mean a socialism that is tailored to Chinese conditions and has a specifically Chinese character....Socialism means eliminating poverty. Pauperism is not socialism, still less communism (Deng Xiaoping, Socialism with Chinese Characteristics [1]).

..China's rise is not the rise of an ordinary state, but the rise of a country, sui generis, a civilizational state, a new model of development and a new political discourse which questions many of the Western assumptions about democracy, good governance and human rights, and all this may usher in a wave of change unprecedented in human history. Zhang Weiwei, The China Wave [2]).

\section{Keywords:}

Daoism;

Philosophic Foundation;

Chinese Economic;

Conjecture.

Article History:

$\begin{array}{cccc}\text { Received: } & 04 & \text { June } & 2018 \\ \text { Accepted: } & 17 & \text { August } & 2018\end{array}$

\section{1- Introduction}

Western economic theory offers two broad categories of economic organization, one beginning with Smith is based upon free markets, the other, presented by Hayek in The Road to Serfdom, is a Soviet style planned economy where production is organized down to the last nut and bolt. The conjecture presented here suggests that the Chinese economy is indeed based upon Chinese characteristics. China has a long and distinguished cultural and philosophic tradition offering rich experience and philosophic organizational ideas. We propose that China offers a third broad category of Eastern economic development and organization using Daoist principles. Others seem to be coming to this conclusion also $>[3,4]$ hang comments "(i)n all fairness with three decades of reform, the gap between many parts of China and the developed countries is narrowing quickly, and the developed countries have been a bit too complacent for too many years, believing that they represent the best of everything in the world, and history has come to an end with the Western political and economic model. Yet China is redefining what constitutes modernization" [2]. We do not suggest that the Chinese Communist Party adopted Daoism wholesale, just that aspects of Daoism offer a uniquely Chinese method of market organization. Marx did not offer a roadmap for the achievement of socialism and communism. Lenin died before the full implementation of the New Economic Policy and Mao's policies were discredited. Schell and Delury argue that Chinese Legalism, with its emphasis on wealth and power, became the overarching political philosophy in the Post-Mao era [5]. A limited use of markets would `allow China to achieve both.

The challenge confronting Deng and the other reformers was enormous: how do you modernize one of the most populous countries in the world within the context of China's history and tradition? To phrase it differently: what is the

* CONTACT: Edward.romar@umb.edu

DOI: http://dx.doi.org/10.28991/esj-2018-01144

(C) This is an open access article under the CC-BY license (https://creativecommons.org/licenses/by/4.0/). 
proper balance between Chinese characteristics and Western ideas, without setting off another century of humiliation [6]. In his speech founding the Peoples Republic of China Mao said: "Ours will no longer be a nation subject to insult and humiliation. We have stood up" [7]. While China had stood up, it still faced a long road toward achieving respect and its proper place in the world. Modernization would be the way to rectify the situation. Modernization would not simply improve the lives of the Chinese; it would also raise China's stature in the world. This has been one consistent principle supported by every leader from Mao to Xi, from the founding of the Republic until today.

What did Deng really mean by "Marxism that is integrated with Chinese conditions" and how much would be Marxist and Chinese? His ascension to power came after Mao's death, the defeat of the Gang of Four and the tragedy of The Cultural Revolution. The Gang of Four became a convenient scapegoat for the excesses and damage done by Mao to Chinese society and offered an opportunity to craft a new approach to Chinese modernization. Deng's dilemma was how to alter the direction of Chinese economic development without alienating the Maoist traditionalists within the party, the government, the military and society. His answer was to use Mao as the lever to change direction and transform society. The end of the $20^{\text {th }}$ Century witnessed the fall of Soviet Communism and the beginning of Deng's reforms in China. This led one commentator to proclaim "the end of history."

"The triumph of the West, of the Western idea, is evident first of all in the total exhaustion of viable systematic alternatives to Western liberalism. In the past decade, there have been unmistakable changes in the intellectual climate of the world's two largest communist countries, and the beginnings of significant reform movements in both" [8].

In 2018, this type of analysis seems quaint. Russia has not developed into a liberal state and neither has China. If anything, the world now has three great powers, only one of which may be characterized as liberal. In reality, the East remains culturally and philosophically different from the West. Contemporary China is often portrayed as authoritarian capitalism. But is this so? The label "authoritarian capitalism" seems to fit $20^{\text {th }}$ Century Fascism and Latin America military regimes better than China. True, the Peoples Liberation Army is a pillar of the regime, but remains firmly under political control and the economy is not western liberal with an independent, free market but one where markets are a useful tool for development and under the firm grip of the political leadership. It is better to look elsewhere for the foundation of Chinese legitimacy than Western political categories. Indeed, while China possesses many aspects of a modern, Western society, its foundation is fundamentally Eastern. Whereas the West has a sense of change and progress toward some end point, the East has a sense of change and balance found in both Confucianism and Daoism without a specific end point. As Lee Kuan Yew remarked, "Life is a marathon without a finish line"[9].

Fan offers a useful analysis of the differences between Chinese and Western political development. He argues that much of Western thought is grounded in Christianity with its emphasis on individuals and progress from birth to death and either eternal reward or damnation. As he argues, "(a)mong the major cultural differences that distinguish China from the West is that China is not a Christian country" [10]. He adds that Western concepts such as freedom, democracy and human rights are not part of the Chinese tradition and experience. Zhang argues that China's political philosophy, culture and traditions extend back millennia. We might add that China did not experience the Western Enlightenment nor does it have a social contract tradition like Hobbes, Locke and Nozick. Therefore, Fukuyama's end of history and the triumph of liberalism neglected to include a substantial portion of humanity and highlights how the West misunderstands contemporary China.

Using the "Varieties of Capitalism" approach where capitalist systems are understood on a continuum from US style liberal market economies to German style coordinated market economies, Peck and Zhang argue that approaches to understanding Chinese economic behavior are forced into Western analytical categories that cannot understand the Eastern origin and behavior of China. They go so far as to suggest that China represents a unique form of economic organization that does not fit well with the Asian model of South Korean and Post WW II Japan, since both organized their economies within US led alliances. They argue "it would appear that the Chinese case is 'just too different' to be shoehorned into extant state-theoretic categories'... having rapidly evolved from a socialist-development-state into a hybrid system which is no longer socialist but which cannot be properly understood as capitalist either: a post-socialist development state" [11].

Similarly, Wing-jer Chen views the Chinese "middle way" as fundamentally different from the West.

In contrast to the Western analytical way of thinking, which is based on breaking the whole into parts, the Chinese mindset takes an integrative point of view, one that considers all things in terms of their relationships, be they social, economic, or biological [12].

He continues his analysis by arguing that Chinese mindset is able to retain opposing perspectives by seeking a "middle way philosophy (which) embraces two opposing but interdependent ideas: holism and paradox" [12]. Managing these interdependent ideas leads to the process of achieving harmony. Western rationalism requires the reconciliation of opposing ideas through a synthetic dialectical linear movement. Eastern thought seeks not synthesis but harmony, through a cyclical harmonizing process. 


\section{2- Deng's Reforms}

Chinese philosophy is pragmatic and looks to practical solutions to challenges. Theoretical understanding alone will not provide solutions to challenges. Theory must be aligned with the real world and if the solutions are successful that is sufficient; if not, new solutions must be tried.

As far as social movements are concerned, true revolutionary leaders must not only be good at correcting their ideas, theories, plans or programmes when errors are discovered, as has been indicated above; but when a certain objective process has already progressed and changed from one stage of development to another, they must also be good at making themselves and all their fellow-revolutionaries progress and change in their subjective knowledge along with it, that is to say, they must ensure that the proposed new revolutionary tasks and new working programmes correspond to the new changes in the situation [13].

For the reformers, The Great Leap forward, the Cultural Revolution and the cult of personality made things worse, not better.

China at this time was primarily a peasant, agricultural society and the revolution was a peasant one. According to Vogel, Deng was in Moscow during Lenin's New Economic Program (NEP). It was in Moscow where the seeds of his reforms were sown [14]. His challenge was to dismantle Mao's Stalinist, centrally planned, bureaucratic state while applying Lenin's "commanding heights" and keeping the Chinese Communist Party firmly in control. China does not plan down to the last detail, while adhering to the principles of central planning. It promulgates five year plans which identify industries and social sectors to develop, sets objectives and desired outcomes as well as the resources to accomplish the plan. It then permits other participants the ability to undertake economic activities within the parameters and confines of the plan. This allows for efficient resource allocation, ease of entry into promising industries and signaling what areas to abandon, which directs business into economic sectors of interest to the party and government.

Djilas, in The New Class, offers an insightful analysis of the Communist System. Marx did not present a blueprint for industrialization. Bernstein and Lenin, he argues represent the two extremes of socialist ideology [15]. The effort to realize the socialist dream was connected to Bernstein and Lenin. Bernstein represents the evolutionary wing of Social Democracy more appropriate to the advanced economies of Nineteenth Century Western Europe, which could support democratic institutions and did not need a bureaucratic state. Lenin represented the Eastern, revolutionary, Communist wing. In the East, revolution was necessary because semi-feudal Russia did not have an industrializing economy with working class and bourgeois social forces. Communism, Djilas realized, represents an avenue toward industrial development for late modernizers, which requires industrialization as well as the social development needed to support it.

When The New Class was published, Djilas saw only two possible socialist outcomes: Western social democracy or Stalinist communism. Since communism is a legitimate choice for a late modernizer he was pessimistic about the outcome. He is critical of the Stalinist solution because it created a bureaucratic "new class" that was oppressive since it controlled the national and socialized property and was self-perpetuating. Communism was suffocating and left little space for individuals to control their lives. "Ownership is nothing other than the right of profit and control. If one defines class benefits by this right, the Communists states have seen, in the final analysis, the origin of a new form of ownership or a new ruling and exploiting class" [15].

Deng represents a third approach which is neither Western social democracy nor Stalinist Communism. On December 18, 1978, he gave a speech which gave the Chinese Communist Party a new manifesto and a new mission away from class struggle toward economic growth [16].

As more wealth is created for the state, personal wealth and collective benefits should also be increased somewhat. As far as the relatively small number of advanced people is concerned, it won't matter too much if we neglect the principle of more pay for more work and fail to stress individual material benefits. But when it comes to the masses, that approach can only be used for a short time-it won't work in the long run. Revolutionary spirit is a treasure beyond price. But revolution takes place on the basis of the need for material benefit. It would be idealism to emphasize the spirit of sacrifice to the neglect of material benefit.

We must learn to manage the economy by economic means. If we ourselves do not know about advanced methods of management, we must learn from those who do, either at home or abroad [17].

In 1983, Deng went further in arguing for the importation of foreign economic ideas and the use of foreign experts.

We should make use of the intellectual resources of other countries by inviting foreigners to participate in key development projects and other construction projects in various fields. We haven't recognized how important this is, and consequently we haven't done as much as we should have. In the matter of modernization we have neither experience nor technical knowhow. We should not be reluctant to spend money on recruiting foreigners. 
It doesn't matter whether they stay here for a long time or a short time, or just for a single project. Once they are here, we should make the best use of their skills. We have been giving them too many banquets and have been too hesitant about asking for their help and advice, when in fact they have been quite willing to assist us in our work [18].

China should take from the West the knowledge and technology useful in the modernization process and harness it to Chinese circumstance but insulating society from such Western ideas as freedom, democracy and liberalism. This means foreign investment and joint ventures where technology transfer such as marketing, plant and equipment and logistics could take place in China while insuring that the economy would not be dominated and controlled by Western companies.

The rejection of Western economic liberalism was a deliberate choice for two fundamental reasons. Western economic liberalism was not a Chinese concept and an open and liberal economy would put China at the mercy of more experienced Westerners who could dominate and control Chinese development. The free market capitalism of both Hayek and Friedman reduces government to a social appendage and secondary to the market, leaving the market as the primary system in society or, to put it another way, every institution and organization is subordinate to the market.

Viewed as a means to the end of political freedom, economic arrangements are important because of their effect on the concentration and dispersion of power. The kind of economic organization that provides economic freedom directly, namely, competitive capitalism, also promotes political freedom because it separates economic power from political power and in this way enables the one to offset the other [19].

For Deng it was the opposite, everything was politically driven and markets were a tool for modernization.

\section{3- Stipulations}

It would be silly to argue that Deng and the Chinese reformers applied Daoism in its entirety. Livia Kohn (2001) argues that a weakened form of religious Daoism is all that remains of Daoism in Contemporary China after years of suppression under Communism. However, this does not eliminate the possibility of the revival of elements of political Daoism as the underpinnings of reform. Daoism represents a political philosophy with an ancient heritage. Must a philosophy be explicitly stated to be the foundation of governmental policy, especially one that still claims to be communist? Daoism is a cyclical, preindustrial philosophy applicable to an agrarian society, while Marxism/Leninism/ Maoism are based upon a linear, progressive ideology. However, Daoism remains present in a religious context in contemporary Chinese society, which suggests that Daoist ideas and concepts were available to the reformers as a method to provide economic development "with Chinese characteristics". While it is true that Daoism was a premodern, anti-consumption philosophy, it does not preclude an updated and limited application to markets. Daoism would not be the only philosophy in this context applied in ways unintended by its founders. Daoist concepts such as wu wei, qi and yin-yang are useful in understanding Daoism as a cyclical, autopoiesis system. According to Miller, Daoism is the motivating energy behind many local Chinese economic programs [20]. Daoism is a communal philosophy as is socialism and communism. An objection can be raised that references to Daoism in the various Chinese five year plans and Deng's writings are not present. This is so but it does not eliminate the possibility of Daoist influence in Deng's reforms. Daoism would offer the reformers what Graham argues it offered Confucians: abandoning a prescribed course of conduct (the rigid, centralized Soviet style economic plan) in favor of some economic liberalism found in markets [21]. After all, he and the other reformers were Chinese and educated before the revolution. Furthermore, he was a determined reformer after the defeat of the Gang of Four. He did not wish to continue Mao's policies, which were, for the most part, Stalinism adapted to Chinese conditions. If he wanted Western technology transfer, without Western economic liberalism, Daoist concepts were available from the rich Chinese philosophic tradition. Kohn persuasively argues only some aspects of Daoism such as religious rituals and health and balance concepts (qi gong) are practiced in China today [22]. While this observation is true, Liu Xiaogan suggests that Daoism has contemporary relevance beyond religious ritual and health practices [23].

We must keep in mind the reformers' objectives, which were to modernize the Chinese economy, lift living standards and improve the quality of life for the Chinese people. In the West markets are the means by which profits are made and the products and economic organizations are means to that end. In China markets are a tool for wealth production and economic growth. Profits are necessary to secure the future but their primary purpose is wealth production. China remains a planned economy where 30-40 percent of the economy remains in either national or local government control. They are favored in access to credit and in issuing publically traded financial instruments. Equally important is their preferential position in securing essential inputs such as land, energy and finance. However, the Chinese leaders realized the important role markets play in economic development where the pricing structure signals the efficient allocation of economic resources [23]. To move ahead for a moment we can look at this as wu wei presented in Zhuangzi's "The Primacy of Nourishing Life". Wu wei is usually translated as non-action but it can mean also little action or effortlessness. In "The Primacy of Nourishing Life" the cook is so good at his task and performs it so well that he does not need to sharpen his knife. In a sense, the story is metaphorical for understanding natural processes. If we understand 
the Dao and how natural processes unfold we are in a good position to perform effortlessly [25, 26].

\section{4- Daoism and Chinese Markets}

Deng and the reformers faced a daunting challenge: how to continue Chinese modernization begun under Mao and accomplish it by acquiring and applying Western science and technology within the context of "socialism with Chinese characteristics". Chinese philosophic tradition is rich and offers several approaches. Confucianism had long held sway in China. While important as a governing philosophy, Confucianism, with its emphasis on hierarchy and relationships offers little in the way of organizing a dynamic, market based economy. Legalism with its emphasis on rules and punishments does not lend itself to the risk-taking motivations needed for market success. Daoism does. As Chan Wing -Tsit observed, there are some similarities in Daoism with laissez-faire [26]. While the Chinese Communist Party did not wish to implement Western free market capitalism, there is much attractive in Daoism for the transition from a fully planned economy to one liberalized to allow limited market operations. To be clear, markets are a tool, not an end and the state will remain in control of modernization and economic development.

We must keep in mind that in the beginning of reform as well as today that China was/is not a fully formed market economy. The Communist Party and the government remain important players in the economy and control significant aspects of economic activity. From the standpoint of markets this illustrates wu wei, where the party gives the push which catalyzes change.

If "(s)ocialism means eliminating poverty (and) (p)auperism is not socialism, still less communism" then a Daoist market organization makes sense in the process of "building socialism with Chinese characteristics." In the West markets are wealth producing through the profit motive. From an Eastern perspective profit is the result rather than the primary motivation, which is wealth production and social contribution. Through wu wei, yin/yang and other Daoist ideas markets can produce wealth and make social contributions. Nonaction, or effortlessness can contribute to market success. By understanding the market, decent preparation and timing, it is possible to create successful organizations and products. This is the primary responsibility of leaders.

"For truly Being and Not-Being grow out of one another.

Long and short test one another;

High and low determine one another.

The sounds of instrument and voice give harmony to one another.

Front and back give sequence to one another'.

Therefore the Sage relies on actionless (sic) activity,

Carries on wordless teaching,

But the myriad creatures are worked upon by him; he does not disown them.

He rears them, but does not lay claim to them,

Achieves his aim but does not call attention to what he does;

And for the very reason that he does not call attention to what he does

He is not ejected from fruition of what he has done. [27, Chapter II]."

A Daoist approach to markets is fundamentally different than Adam Smith's which implies a plan and end point. A Daoist approach implies a neutral and spontaneous approach that does not suggest a plan. There is not an invisible hand which assists market dynamics and accomplishes wealth production. It does leave firms to their fate by requiring business to be commercially viable, which the market will determine. This applies to the State Owned Enterprises as well, even though they receive some preferential treatment by the state because of their key role in national security and social economic success. Every commercial entity must follow its Dao.

There is much more going on here, however. The business person seeks to participate successfully in the market and the market does not care who wins or loses. Yet the business person is not powerless, though his knowledge is incomplete. Just as the farmer knows the seasonal cycles and when to plant and harvest; he knows not whether there will be drought or heavy rain that will affect his bounty. Similarly, the business person does not know how the market will behave and whether his product or business will survive. Timing and fortuitousness are important too. For both the farmer and the business person there is paradox. The more they try the more they may fail and if conditions are correct, the less they try the more they can succeed.

One can observe, also, a natural process as markets develop new products and techniques. As Liu observed, there is a naturalism in the Dao that is not "necessarily opposed to any kind of transformation or reformation" but in all cases must maintain harmony and balance". He remarks further, if a farmer "discovered an improved way of making a living because of certain transformations in society and pursued it without coming into conflict with others, the change would be conceived as natural, despite the radical change in his life" [23]. Successful business leaders do not impose their will on markets because this action is usually unsuccessful. This is illustrated by an example from the USA. Steve Case CEO 
of an early Internet service provider AOL, America on Line, engineered an acquisition of media content giant TimeWarner. The merger failed and AOL divested Time-Warner because the technology was not sufficiently developed and the market not sufficiently prepared for the scheme to succeed. However, Comcast successfully acquired NBC Universal because the technology was available, the market was ready and GE, the NBC Universal parent company was willing to sell. Jack Ma, the founder of Alibaba successfully launched his Internet based company. Amazon validated the basic model. Ma perceived the Chinese opportunity, used access to the Internet through foreign servers and was well positioned when telecommunications were liberalized in China [28].

It is possible also to see a natural process of decay and renewal in markets. There is a life cycle for products, markets and there are "sunshine" and "sunset" industries. For example, prior to the advent of mechanized transportation, the movement of goods and people depended to a large extent upon animal and human muscle power. This enabled an industry to develop providing harnesses, whips and so forth for the animals. As new materials and processes developed, new products were introduced into the market, which illustrates the concept of product life cycle from introduction to demise in a continuous process. Furthermore, as mechanized transportation developed and improved it eliminated the need for large animal populations and the products needed for them. This necessitated market participants to exit the industry or remain with reduced opportunities.

While markets are fundamentally about economic exchange between buyers and sellers they need products and services to complete the transactions. This process can be understood through Daoist naturalism. Markets need constant renewal and replenishment to remain dynamic. In the retail industries, especially, one measure of success and profitability is the number of times the inventory turns over during a period of measurement (month, quarter, and year). Therefore, renewal and replenishment can be viewed not only from a retailer's perspective but also from supplier firms and their suppliers. Depending upon the size of the economy this can be a large and complex process, enabling a dynamic process of economic activity and wealth creation.

Daoism would understand markets through emptiness and fullness. Chapter XI of the Tao Te Ching says,

"We put thirty spokes together and call it a wheel;

But it is on the space where there is nothing that the utility of the wheel depends.

We turn clay to make a vessel;

But is on the space where there is nothing that the utility of the vessel depends.

We piece doors and windows to make a house;

And it is on these spaces where there is nothing that the utility of the house depends.

Therefore just as we take advantage of what is, we should recognize the utility of what is not." [27, Chapter XI]"

Similarly, in Chapter V the imagery of emptiness/ fullness is illustrated by the bellows.

“...Yet Heaven and Earth and all that lies between

Is like a bellows

In that it is empty, but gives a supply that never fails

Work it, and more comes out..." [27, Chapter V]."

There is, therefore, a natural and cyclical process to markets. Markets come and go, products come and go in a process of decline and rebirth as they seek a harmony in the course of a never ending process of balance and change. Marketing processes are paradoxical in that there is no clear plan and direction. While things seem designed, outcomes are accidental and markets do not care who wins or loses or if anyone does win or lose. As Schwartz observed,

"The processes of nature are not guided by a teleological consciousness...the tao is not consciously providential. ...Heaven and earth do not concern themselves with the weal and woe of individual humans or of other creatures. One indeed may say that Lao-tzu's is an order which runs spontaneously and without deliberate planning or premeditation" [29, italics in the original]"

Zhuangzi offers a view of the paradox of usefulness and uselessness that can be applied to markets. Usefulness is obvious but the usefulness of uselessness is less so. Uselessness conceals the usefulness of what is hidden and underneath. The paradox of unity and connectedness illustrates a natural harmony of opposites. ${ }^{*}$ Innovators should keep

* This should be kept in mind when evaluating the market and non-market governance of China. An analysis based upon Coase might be instructive [31]. 
in mind the idea of instrumentality.

"Huizi said to Zhuangzi, 'The King of Wei gave me the seed of a great gourd. I planted it, and when it matured it weighed over a hundred pounds. I filled it with liquid, but it was not firm enough to lift. I cut it in half to make a dipper, but it was too large to scoop into anything. It was big and all, but because it was so useless, I finally just smashed to pieces."

Zhuangzi said, "You are certainly stupid when it comes to using big things." [25, Chapter One: Wandering Far and Unfettered]

Just like the bellows and the wheel, the gourd had usefulness and its usefulness must be recognized and understood to be useful.

Yin/yang and qi energy complement market activity. In the market process yin, strong force, and yang, weak force, interact in several ways. According to Moeller Chapter XLII in the Daodejing is the only place where Yin/yang are mentioned specifically [30].

"Tao gave birth to the One, the One gave birth successively to two things, up to ten thousand.

These ten thousand creatures cannot turn their backs to the shade without having the sun on their bellies, and it is on this blending of their breaths that their harmony depends... [27, Chapter LXII]."

Zhuangzi offers another view of the yin/yang interactive process and provides another look at their applicability to market participants.

"What gives birth to all the living is not born. It is something that sends all beings off and welcomes all beings in, destroys all and completes all. Its name is the Tranquility of Turmoil. This Tranquil Turmoil! It is what reaches completion only through its turmoil...The Great Clump burdens me with a physical form, labors me with life, eases me with old age, and rests me with death. Hence it is precisely because I regard my life as good that I regard my death as good. [25, Chapter Six: The Great Source as Teacher]".

Zhuangzi captures the cyclical nature of markets and products quite well. The Tranquil Turmoil illustrates the recurring energy of market dynamics with repetitive cycles of building and destruction, as well as the impact of the process on people. Strong/weak, light/dark are the complementary, interactive, natural forces which comprise the process of change. This process itself is driven by qi energy or vital force which is within everything and connects everything. From a marketing perspective this process governs relationships among customers, firms, suppliers, government and so forth.

The Special Economic Zones (SEZ) provide an example of how wu wei, yin/yang and qi energy can support economic development, market activities and wealth and power. They were conceived as experiments where economic organization and political reform could be tested in isolation from the remainder of China. Deng was very clear in the objectives and limitations of the reform.

"In our reforms, on the premise of persisting in the planned economy, we have delegated greater power to local administrations and enterprises and given scope to the supplementary role of regulation through the market. ...The individual economy of urban and rural working people operating within certain prescribed limits and under state control is a necessary complement to the public sector of the economy. ...But the state will not permit any activities in the individual sector of the economy to undermine the socialist economy" [18].

In the SEZs the government set the objectives and outer limits of behavior of the SEZ administration and selected the local leadership responsible for implementation. The local administration would then select the people and firms, including foreign firms, to develop the market economy. This is wu wei, also, and yin/yang, where the government in Beijing represented the strong force and the local government was the weak force in the administrative relationship. Locally, the government represents the strong force and the firms, especially the foreign ones, represented the weak force.

The SEZs allowed the government to manage foreign firms' reentry to China without being charged with allowing the redevelopment of the Western economic imperialism of the recent past, while gaining access to the desperately needed investment, technology and expertise of the West.

"From the beginning, Shenzhen and its sister SEZs were meant not merely to process exports but to act as thresholds through their exceptional status. The zone is not fully home or abroad-it is at the same time both inside and outside the system. This is the zone's particular strength, what allows the zone to let goods, money, people and ideas to circulate in ways that might not otherwise be possible. In Shenzhen, as in other cases, the zones as thresholds serves two limited functions that propel it from a site of production to a site of transformation. First, the zone serves as a spatial threshold that mediates between China's economic space and that of other countries-as in the 'window to the world' as the leadership called it - through which one can look in and out, 
second, the zone serves as a temporal threshold between stages of development - the China that was and the China that will be. Deng and his supporters were explicit about the SEZs serving as places to test out reforms that could later be extended to the whole country. By dint of this threshold function, the hope was that the zone would indeed have a magical effect of sorts, transforming the rest of the country in the process. Further, they were to serve as a link to not only global capital but overseas Chinese in particular, thus incorporating and reshaping networks and trajectories of Chinese beyond China" [32, italics in the original]."

We see here also qi energy at work: the connectedness of the local Chinese community, the national Chinese Community, the overseas Chinese and foreign firms, in a circumscribed way, engage in a mutual cooperative effort.

Equally important is the objective of the opening for foreign firms. Foreign access would be well managed and market share regulated. Unlike the Nineteenth Century of national humiliation, Chinese sovereignty would be protected and firms would enter on Chinese terms. Dunne chronicles General Motor's experience navigating the labyrinth of bureaucracy meant to insure that skills and technology were transferred. He illustrates the challenges China presents from getting licenses to do most anything, even repatriating money. He adds, though, that once inside "it is unfettered capitalism within the arbitrary bounds outlined by the Party and its governmental officials (Dunne, p.10). He also points to why General Motors would want access to the Chinese market: it was a large business opportunity. "With all those people, just think how giant China's car market could one day be! We could make a killing just selling hubcaps!” [33 italics in the original]. The party/state continues to set the conditions and limits to the companies' behavior within Chinese markets to secure technology transfer from foreign firms. "The Communist Party's rise in the Chinese offices and factories of foreign companies is yet another challenge to multinationals doing business in the country...Foreign companies face growing pressure to share sensitive technology. The Chinese authorities have stepped up efforts to foster a new generation of homegrown competitors meant to someday to replace foreign companies" [34]. Jamie Kynge argues in a Financial Times piece that President Trump forgets how much trade US companies are doing in China and suggests that trade deficits are not large when compared to Chinese sales for foreign companies [35]. This is a half - truth and compares apples to oranges. The trade deficit affects the US economy. However, when the repatriation of profits is taken into consideration, the situation is much different. China makes it difficult to repatriate the profits.

\section{5- Conclusion}

Deng and the reformers set the task of modernizing China through the four modernizations of agriculture, industry, science and technology and national defense.

"The key to the four modernizations is the modernization of science and technology. Without modern science and technology, it is impossible to build modern agriculture, modern industry or modern national defence. (sic) Without the rapid development of science and technology, there can be no rapid development of the economy" [18].

Moeller argues that the Daodejing is an example of strategic thinking. At the time the reforms began, China was weak vis- a-vis the West. The goal was for China to strengthen its domestic and international position through the modernization of the four sectors that would enhance its domestic economic base and improve its international standing as a way to prevent another century of humiliation.

The Daodejing offers a strategy for a weaker state through the analogy of water. Water represents another paradox. While it appears weak paradoxically it is strong and powerful.

A large kingdom must be like the low ground towards which all streams flows down. It must be a point towards which all things under heaven converge. Its part must be that of the female in its dealings with all things under heaven. The female by quiescence conquers the male; by quiescence gets underneath. If a large kingdom can in the same way succeed in getting underneath a small kingdom then it will win the adherence of the small kingdom; and it is because small kingdoms are by nature in this way underneath large kingdoms that they win the adherence of large kingdoms The one must get underneath in order to do it; the other is underneath and therefore does it. [27Tao Te Ching, Chapter LXI]

How did the great rivers and seas get their kingship over the hundred lesser streams?

Through the merit of being lower than they; that was how they got their kingship (Tao Te Ching, Chapter LXVI).

This is the foundation of the relationship between weaker and stronger. The weaker must use its weakness against the stronger until the relationship is reversed. This is precisely what the reforms accomplished. By harnessing domestic capabilities and equally important, if not more important, obtaining the knowledge, skills, the capabilities the West was willing to offer, China was able to manage a successful rise. Is this a long-term quest for singularity and inclusive unity? Waley suggests there is "a Primal Unity underlying apparent multiplicity" in Daoism (Waley, 2016). Zhuangzi posits a singularity. "Heaven and Earth are born together with me, and the ten thousand things and I are one" [25]. Pheasant Cap 
Master, who combines Legalism with political and religious Daoism, also sees a cosmic unity in the world and an end to history.

\title{
The Dynamics of Unity
}

From the Way of virtue's law, myriad beings take their livelihoods.

Lacking form but having divisions

Is called the Great Dynamic.

So, when east, west, south and north ways are correctly aligned,

Then their divisions are identical [36, the Top Scroll].

\section{Grand Unity}

\author{
Heaven's nine Galaxies, \\ Earth's nine continents, \\ Grand Unity's Way,
}

The Nine Augustan's teachings,

Their reality was already complete at the grand start's finish [36, Mid Scroll.].

Zhang Weiwei implies that the Western end of history has passed and the eastern has yet to be achieved.

Is this what Deng and the reformers were executing through the limited use of markets and the opening to the West? It is about process, relationships and cycles. These concepts are important to management, marketing and international affairs. There are two overarching aspects of Daoism that are compatible and synergistic with business, economics and international affairs: process and strategy. Process and strategy link Daoist ideas such as wu wei, qi, yin/yang and other concepts. These concepts are interrelated, reinforcing, creating a non-teleological, autopoiesis, self-generating process.

Daoist wu wei offered Deng and the reformers a way to modernize within both the current economic planning regime and the desire for economic reform. At the same time modernization developed the nation's capabilities over time. The Chinese planning process identifies the economic and national security objectives for the next 5 years. It is therefore a policy as well as a directive for action, which makes it a focus for governmental activities as well as a motivation for behavior. Economic reform and the transition to markets also provided the reformers with the most important source of economic development: dynamic-pricing. Pricing sends important signals to market participants and allows for the allocation of resources more efficiently than does a totally planned economy, as the former Soviet Union demonstrated. In China the state controls significant economic levers in the state owned enterprises (SOEs) and banks. According to the US State Department "SOEs, both central and local, account for 30 to 40 percent of total GDP and about 20 percent of China's total employment" [37]. In addition, the largest Chinese banks are state owned, including the Asian Infrastructure Development Bank, and have substantial assets and working capital.

To put this into Daoist terms, the planning process can be seen as wu wei, the little action of opening markets. Favorable financial investment can direct economic development and provide economic stimulation, leaving SOEs and private firms to develop new industries, new products and enter new markets, thus demonstrating non action, or little action. These, taken together in reinforcing relationships, contributed significantly in China's rise and continued development.

\section{5- References}

[1] Deng Xiaoping, Socialism with Chinese Characteristics, June 30 , 1984 http://www.china.org.cn/english/features/dengxiaoping/103371.htm, downloaded 3/13/18.

[2] Zhang Weiwei, “The China Wave: The Rise of a Civilizational State.” (2012). World Century, Hackensack, NJ.

[3] Browne, Andrew, “The West Faces Up to Reality: China Won't become 'More Like Us.” The Wall Street Journal. (December 12, 2017). https://www.wsj.com/articles/the-west-gets-real-about-china-1513074600 downloaded 7/18/2017.

[4] Campbell. Kurt M. and Ely Ratner, “The China Reckoning: How Beijing Defied American Expectations.” Foreign Affairs, March/April (2018): 60-71.

[5] Schell, Orville and John Delury, "Wealth and Power: China's Long March to the Twenty-First Century.” (2013). Random House, NY.

[6] Wang, Zheng, Never Forget National Humiliation: Historical Memory in Chinese Politics and Foreign Relations. (2012) Columbia 
University Press, NY.

[7] Mao Zedong, "The Chinese People Have Stood Up," https://www.marxists.org/reference/archive/mao/selected-works/volume5/mswv5_01.htm. downloaded: 7/19.2018.

[8] Fukuyama Francis, “The End of History?” https://www.embl.de/aboutus/science_society/discussion/discussion_2006/ref122june06.pdf downloaded, 3/18/18.

[9] Lee, Terence, "The politics of Civil Society in Singapore.” Asian Studies Review, 26 no. 1 (March 20): 97-117. Doi:10.1080/10357820208713332.

[10] Qing, Jiang. "From Mind Confucianism to Political Confucianism.” The Renaissance of Confucianism in Contemporary China (2011): 17-32. Doi: 10.1007/978-94-007-1542-4_2.

[11] Peck, Jamie and Jun Zhang, “A Variety of Capitalism...with Chinese Characteristics.” Journal of Economic Geography, 13, no. 3, (May 2013): 357-396. Doi: 10.1093/jeg/lbs058.

[12] Chen, Ming-jer, "Transcending Paradox: The Chinese "Middle Way" Perspective.". Asia Pacific Journal of Management. 19, no. 2-3 (2002): 179-199. Doi: 10.1023/A:1022024730957.

[13] Mao Zedong, “On Practice: On the Relation between Knowledge and Practice, Between Knowing and Doing," (1937). https://www.marxists.org/reference/archive/mao/selected-works/volume-1/mswv1_16.htm, downloaded 6/12/18.

[14] Vogel, Ezra F., Deng Xiaoping and the Transformation of China. (2011) Belknap Press of Harvard University Press, Cambridge, MA.

[15] Djilas, Milovan, “The New Class: An Analysis of the Communist System.” (1957\} Frederick A. Praeger, NY.

[16] Kuhn, Robert Lawrence, "How China's Leaders Think: The inside Story of China's Reform and What this means for the Future." (2010) Wiley, Hoboken, NJ.

[17] Deng Xiaoping, "Emancipate the Mind, Seek Truth from Facts and Unite as One in Looking to the Future,” Deng Xiaoping: Speeches and Writings in Speeches and Writings, Robert Maxwell, ed. (1984) Pergamon, NY.

[18] Deng Xiaoping, "Use Intellectual Resources of Other Countries and Open Wider to the Outside World, July 8, 1983. https://archive.org/stream/SelectedWorksOfDengXiaopingVol.3/Deng03_djvu.txt downloaded 3/20/18.

[19] Friedman, Milton, Capitalism and Freedom. (2002). The University of Chicago Press, Chicago, IL.

[20] Miller, James, "Daoism and Development," in, Clarke, Mathew ed. (2013), Handbook of Research on Development and Religion. 2013). Edward Elgar, Northampton, MA: 113-123.

[21] Graham, A.C.," Disputers of the Tao: Philosophic Arguments in Ancient China. “(1989). Open Court, Chicago, IL

[22] Kohn, Livia, "Daoism and Chinese Culture." (2002). Three Pines Press, St. Petersburg, FL.

[23] Liu Xiaogang, Naturalness (Tzu-jan), “The Core Value in Taoism: Its Ancient Meaning and Its Significance Today,” in Lidia Kohn and Michael Lafargue, eds. Lao-tzu and the Tao-te-Ching, (1998). State University of New York Press, Albany, NY.

[24] Hayek, F. A, “The Road to Serfdom.” (1994). The University of Chicago Press, Chicago, IL.

[25] Zhuangzi, "The Essential Writings with Selections from Traditional Commentaries" Brook Ziporyn, Trans. (2009). Hackett Publishing Co., Indianapolis, IN.

[26] Chan Wing-Tsit. “A Source Book in Chinese Philosophy.” (1963). Princeton University Press, Princeton, NJ.

[27] Waley, Arthur (The Way and Its Power: A study of the Tao Te Ching and Its Place in Chinese Thought. (2016) Martino Publishing, Mansfield Centre, CTR.

[28] Clark, Duncan, Alibaba: The House that Jack Ma Built. (2016). HarperCollins, NY.

[29] Schwartz, Benjamin I (1985), “The World of Thought in Ancient China.” (1985). The Belknap Press, Cambridge, MA.

[30] Moeller, Hans Georg, "The Philosophy of the Daodejing. (2006). Columbia University Press, NY.

[31] Coase, R. H., “The Firm, the Market and the Law.” (1990). The University of Chicago Press, Chicago, IL.

[32] Bach, Johnathan “Shenzhen: From Exception to Rule," in O’Donnell, Mary Ann, Winnie Wong, and Johnathan Bach, "Shenzhen: China's Post-Mao Experiment from Special Zone to Model City,” (2017) The University of Chicago Press, Chicago, IL.

[33] Dunne, Michael J., “American Wheels, Chinese Roads: The Story of General Motors in China”. (2011). John Wiley and Sons (Asia) Singapore.

[34] Stevenson, Alexandra, “China’s Communists Rewrite the Rules for Foreign Businesses,” The New York Times, (April 13, 2018). 
https://www.nytimes.com/2018/04/13/business/china-communist-party-foreign-businesses.html, downloaded 6/18/18.

[35] Kynge, James, “Trump Forgets that US Companies in China are doing a roaring trade”. Financial Times, https://www.ft.com/content/170b7016-746c-11e8-aa31-31da4279a601 downloaded 6/20/18.

[36] Wells, Marnix," “The Pheasant Cap Master and the End of History.” (2013). Three Pines Press, St. Petersburg, FL.

[37] U.S. Dept. of State: https://www.export.gov/article?id=China-State-Owned-Enterprises. Downloaded: May 30, 2018. 